\title{
Meningkatkan Hasil Belajar Siswa melalui Model Number Head Together Berbantuan Mind Mapping
}

\author{
Poso Sumarto \\ SDN Beloh Kecamatan Trowulan Mojokerto \\ Email : pososumarto.pupns@gmail.com
}

\section{Tersedia Online di \\ http://www.jurnal.unublitar.ac.id/ index.php/briliant}

\begin{tabular}{l}
\hline Sejarah Artikel \\
\hline Diterima pada 31 Maret 2017 \\
Disetuji pada 5 April 2017 \\
Dipublikasikan pada 1 Mei 2017 \\
Hal. 147 - 153 \\
\hline
\end{tabular}

\begin{tabular}{l}
\hline Kata Kunci: \\
$\begin{array}{l}\text { number head together, } \text { mind } \\
\text { mapping }\end{array}$ \\
\hline
\end{tabular}

\begin{abstract}
Abstrak: Penelitian ini adalah penelitian tindakan kelas. Penelitian ini bertujuan untuk meningkatkan aktivitas dan hasil belajar peserta didik melalui pembelajaran kooperatif tipe NHT (Numbered Head Together) dengan media Mind Mapping pada materi pokok luas bangun datar. Subjek penelitian ini adalah peserta didik kelas VI di SDN Beloh Trowulan Mojokerto. Berdasarkan analisis data, secara klasikal menunjukkan bahwa hasil belajar peserta didik pada siklus I sebesar $42,50 \%$ dan pada siklus II mengalami peningkatan sebesar $40 \%$ menjadi $82,50 \%$. Sehingga dapat dikatakan bahwa ketuntasan hasil belajar didik telah tercapai pada siklus II.
\end{abstract}

Pendidikan merupakan ujung tombak kemajuan sebuah bangsa. Bangsa akan menjadi maju apabila memiliki Sumber Daya Manusia (SDM) yang berkualitas atau bermutu tinggi. Adapun mutu bangsa dikemudian hari tergantung pada pendidikan yang diberikan generasi masa kini, terutama melalui pendidikan yang formal yang diterima disekolah.

Menurut Syam (dalam Ahmadi, 2014:4) "pendidikan sebagai aktivitas dan usaha manusia untuk meningkatkan kepribadiannya dengan jalan membina potensi-potensi pribadinya, yaitu rohani dan jasmani".Untuk meningkatkan kepribadian maka peserta didik harus mengembangkan kemampuan belajarnya, sehingga peserta didik dapat lebih aktif dan mandiri dalam pembelajaran. Pada kenyataannya peserta didik masih saja tergantung pada penjelasan guru. Khususnya pada mata pelajaran matematika. Sehingga matematika dianggap sebagai momok yang besar dalam pembelajaran.

Untuk itulah diperlukan revolusi belajar yang dapat membuat pembelajaran menjadi lebih berwarna, lebih bergairah, aplikatif dan mudah. Dengan adanya pemilihan pembelajaran Kooperatif tipe NHT (Numbered Head Together), selain agar siswa lebih memahami konsep pembelajaran secara menyuluruh siswa pun dapat lebih aktif dalam menyampaikan materi secara mandiri.

NHT atau penomoran berpikir bersama adalah merupakan jenis pembelajaran kooperatif yang dirancang untuk mempengaruhi pola interaksi peserta didik dan sebagai alternatif terhadap struktur kelas tradisional. (Trianto, 2007:62).Dalam tipe pembelajaran ini setiap peserta didik diberi nomor kemudian dibuat suatu kelompok kemudian secara acak guru memanggil nomor dari peserta didik. Disini ketergantungan positif juga dikembangkan dan yang kurang, terbantu oleh yang lain. NHT merupakan tipe pembelajaran yang melibatkan lebih banyak 
peserta didik dalam menelaah materi pelajaran dan mengecek pemahaman mereka terhadap isi pelajaran tersebut. Sehingga diharapkan para peserta didik akan terlibat dalam proses pembelajaran yang tuntas dan bermakna (Lindayani dan Murtadlo, 2011:113).

Dari berbagai media pembelajaran yang sudah ada, maka media mind mapping bisa dikatakan sebagai sesuatu yang berbeda. Media mind mapping merupakan media pembelajaran dengan teknik grafis yang mendorong pemikiran kedua sisi otak, secara visual memperagakan berbagai macam hubungan antara gagasan, dan meningkatkan kemampuan untuk memandang masalah dari berbagai sisi. Media mind mapping adalah media pembelajaran yang dapat membantu peserta didik untuk mencatat dan meringkas materi pelajaran dengan lebih efektif, efisien, kreatif, menarik, mudah dan berdaya guna.

Penerapan pembelajaran kooperatif NHT dengan media mind mapping diharapkan dapat meningkatkan hasil belajar matematika peserta didik kelas VI SDN Beloh Trowulan Mojokerto terutama pada mata pelajaran matematika. Karena bagi sebagian besar peserta didik mata pelajaran matematika adalah hal yang sulit dipahami dan diingat melihat banyak rumus atau konsep yang terkandung didalamnya, seperti pada materi pokok luas bangun datar. Kurangnya pemahaman terhadap materi juga akan mengakibatkan kurang maksimalnya hasil belajar peserta didik.

Selain peningkatan hasil belajar yang diharapkan dengan penerapan pembelajaran kooperatif NHT dengan media mind mapping, diharapkan adanya peningkatan aktivitas belajar peserta didik. Aktivitas peserta didik adalah kegiatan yang dilakukan oleh peserta didik selama proses belajar (Sardiman, 2011:100). Aktivitas yang timbul dari siswa akan mengakibatkan pula terbentuknya pengetahuan dan keterampilan yang akan mengarah pada peningkatan prestasi.

Menurut Briggs (dalam Ekawarna, 2013:69) hasil belajar yang sering disebut dengan istilah "scholastic achievement" atau "academic achievement" adalah seluruh kecakapan dan hasil yang dicapai melalui proses belajar mengajar di sekolah yang dinyatakan dengan angka-angka atau nilai-nilai berdasarkan tes hasil belajar.

Berdasarkan uraian diatas, maka rumusan masalah dalam penelitian ini adalah: (1) Bagaimanakah pembelajaran Kooperatif NHT (Numbered Head Together) dengan media Mind Mapping dapat meningkatkan aktivitas belajar peserta didik kelas VI di SDN Beloh Trowulan Mojokerto Tahun Pelajaran 2015/2016? (2) Bagaimanakah pembelajaran Kooperatif tipe NHT (Numbered Head Together) dengan media Mind Mapping dapat meningkatkan hasil belajar matematika peserta didik kelas VI di SDN Beloh Trowulan Mojokerto Tahun Pelajaran 2015/2016?

Berdasarkan perumusan masalah di atas, penelitian ini bertujuan untuk: (1) Untuk mengetahui bagaimanakah pembelajaran Kooperatif tipe NHT (Numbered Head Together) dengan media Mind Mapping dapat meningkatkan aktivitas belajar peserta didik kelas VI di SDN Beloh Trowulan Mojokerto Tahun Pelajaran 2015/2016. (2) Untuk mengetahui bagaimanakah pembelajaran Kooperatif tipe NHT (Numbered Head Together) dengan media Mind Mapping dapat meningkatkan hasil belajar matematika peserta didik kelas VI di SDN Beloh Trowulan Mojokerto Tahun Pelajaran 2015/2016.

148 BRILLIANT: Jurnal Riset dan Konseptual Volume 2 Nomor 2, Mei 2017 


\section{METODE}

\section{Rancangan Penelitian}

Jenis penelitian yang digunakan adalah Penelitian Tindakan Kelas (PTK), yang mengkombinasikan prosedur penelitian dengan tindakan substantif, yang berusaha mengkaji dan merefleksi suatu model pembelajaran dengan tujuan meningkatkan kualitas (baik proses maupun produk) suatu pembelajaran.

\section{Subjek Penelitian}

Subjek penelitian ini adalah kelas VI SDN Beloh Trowulan Mojokerto tahun pelajaran 2015/2016. Kelas tersebut berjumlah 40 orang yang terdiri dari 23 siswa laki-laki 17 siswa perempuan.

\section{Teknik Pengumpulan Data}

\section{Metode observasi}

Adapun data yang ingin diperoleh peneliti yaitu mengenai pelaksanaan pembuatan dan penggunaan media Mind Mapping melalui pembelajaran kooperatif tipe NHT untuk meningkatkan hasil belajar peserta didik kelas VI mata pelajaran matematika.

\section{Metode tes}

Metode tes yang digunakan adalah untuk mengetahui apakah pembuatan dan penggunaan media Mind Mapping dapat meningkatkan hasil belajar dalam belajar matematika setelah dilakukan pembelajaran dengan menggunakan pembelajaran kooperatif tipe NHT. Tes yang digunakan adalah tes tertulis, esai, dan diberikan di setiap akhir siklus.

\section{Instrumen Penelitian}

\section{Lembar observasi}

Observasi menggunakan seluruh alat indra. Observasi perlu direncanakan dan juga didasarkan dengan keterbukaan pandangan dan pikiran serta bersifat responsif. Lembar observasi yang digunakan dalam penelitian ini adalah lembar observasi aktivitas siswa.

\section{Tes}

Tes ini diberikan untuk mengetahui hasil belajar peserta didik setelah diterapkan pembelajaran kooperatif tipe NHT dengan menggunakan media Mind Mapping yang dilakukan dalam setiap siklus dalam mata pelajaran matematika pada materi pokok luas bangun datar, soal dibuat dalam bentuk soal uraian.

\section{Teknik Analisis Data}

Setelah data terkumpul dari hasil pengumpulan data, maka data tersebut perlu diolah dengan cara-cara analisis data. Hal ini untuk menganalisis tingkat keberhasilan atau presentase keberhasilan peserta didik setelah proses pembelajaran setiap siklusnya dilakukan dengan cara memberikan evaluasi berupa soal tes tertulis pada setiap akhir siklus. 


\section{Analisis aktivitas peserta didik}

Analisis data aktivitas peserta didik pada lembar observasi dilakukan dengan memberi skor pada setiap aktivitas yang ada pada lembar observasi dengan kriteria skor sebagai berikut.

$$
\begin{array}{llll}
1 & =\text { kurang } & 3 & =\text { baik } \\
2 & =\text { cukup } & 4 & =\text { sangat baik }
\end{array}
$$

Data hasil observasi peserta didik dapat dianalisis dengan menggunakan rumus sebagai berikut.

$$
X=\frac{\text { jumlah nilai yang diperoleh }}{\text { total aspek yang diamati }} \times 100 \%
$$

Hasil observasi diukur dengan menggunakan kriteria sebagai berikut.

$$
\begin{array}{ll}
90 \%<X \leq 100 \% & =\text { sangat baik } \\
80 \%<X \leq 90 \% & =\text { baik } \\
65 \%<X \leq 80 \% & =\text { cukup } \\
55 \%<X \leq 65 \% & =\text { kurang } \\
X \leq 55 \% & =\text { tidak lulus }
\end{array}
$$

\section{Analisis ketuntasan data hasil belajar}

Berdasarkan kriteria ketuntasan minimal matematika untuk kelas VI di SDN Beloh Trowulan Mojokerto yaitu 70. Seorang peserta didik dikatakan tuntas belajar matematika apabila secara individu memperoleh nilai 70 atau lebih. Untuk dapat mengetahui pencapaian ketuntasan belajar peserta didik, maka data berupa nilai yang diperoleh dengan mengadakan tes pada tiap siklus akan dianalisis dengan batas ketuntasan belajar peserta didik secara klasikal, yaitu :

$$
\text { presentase }=\frac{\sum \text { peserta didik yang tuntas belajar }}{\sum \text { peserta didik keseluruhan }} \times 100
$$

Peserta didik dikatakan tuntas belajar secara individu jika peserta didik tersebut memperoleh skor hasil tes minimal nilai 70 sesuai dengan standart KKM yang telah ditetapkan sesuai dengan kurikulum. Dalam penelitian ini hasil belajar dikatakan meningkat jika peserta didik yang mendapatkan nilai $\geq 70$ secara klasikal sebanyak $70 \%$ peserta didik tersebut tuntas belajar.

HASIL

Siklus I

\section{Perencanaan}

Pada tahapan ini kegiatan yang dilakukan terdiri dari: 1. Mempersiapkan rencana pelaksanaan pembelajaran. 2. Mempersiapkan instrument penelitian berupa lembar observasi aktifitas peserta didik dan lembar soal tes.

\section{Pelaksanaan}

Siklus I dilaksanakan pada tanggal 24 oktober 2015 dan 31 oktober. Siklus I diadakan dua kali pertemuan dalam waktu pembelajaran $4 \times 35$ menit. Pada pertemuan pertama kegiatan di isi dengan kegiatan berkelompok dengan pembelajaran kooperatif tipe NHT untuk membuat mind mapping sebagai 
penunjang pemahaman dalam mempelajari materi luas bangun datar (persegi, persegi panjang, segitiga, jajar genjang, trapezium, layang-layang, belah ketupat, lingkaran). Pembelajaran diakhiri dengan pemberian soal tes siklus I yang dilaksanakan pada pertemuan kedua pembelajaran.

\section{Observasi}

Persentase aktivitas peserta didik pada siklus I sebesar $60 \%$ terletak antara $55 \%<X \leq 65 \%$ dan termasuk dalam kriteria kurang. Dengan demikian hasil analisis bahwa peserta didik dapat dikatakan kurang aktif dalam mengikuti pembelajaran di kelas.

Hasil tes peserta didik pada siklus I diperoleh persentase ketuntasan belajar peserta didik secara klasikal sebesar $42,50 \%$ sehingga pada siklus I secara individu nilai ini belum bisa dikatakan baik karena masih banyak anak yang belum tuntas dalam belajarnya dengan nilai yang kurang baik $(<70)$. Dan secara klasikal belum dapat dikatakan tuntas karena belum mencapai ketuntasan $70 \%$.

\section{Siklus II \\ Perencanaan}

Pada tahapan ini peneliti menyiapkan perangkat pembelajaran untuk siklus II dan menyusun ulang instrument penelitian berupa lembar observasi aktifitas peserta didik dan lembar soal tes .

\section{Pelaksanaan}

Siklus II dilakukan pada tanggal 14 November 2015 dan 21 November 2015 .Siklus II diadakan dua kali pertemuan dalam waktu pembelajaran $4 \times 35$ menit .Pada pertemuan pertama kegiatan di isi dengan kegiatan berkelompok dengan pembelajaran kooperatif tipe NHT untuk membuat mind mapping sebagai penunjang pemahaman dalam mempelajari materi luas bangun datar (luas segi banyak sederhana dan luas gabungan bangun datar sederhana). Pembelajaran diakhiri dengan pemberian soal tes siklus II yang dilaksanakan pada pertemuan kedua pembelajaran.

\section{Observasi}

Persentase hasil observasi aktivitas peserta didik pada siklus II sebesar $90 \%$ terletak antara $80 \%<X \leq 90 \%$ dan termasuk dalam kriteria baik. Dengan demikian hasil analisis bahwa peserta didik dapat dikatakan aktif dalam mengikuti pembelajaran di kelas.

Hasil tes peserta didik pada siklus II diperoleh presentase ketuntasan belajar peserta didik secara klasikal sebesar $82.50 \%$ sehingga pada siklus II hasil belajar peserta didik dikatakan sudah tuntas, karena sesuai harapan yaitu banyak peserta didik yang mendapat nilai 70 minimal 70\%, hal ini menunjukkan bahwa penerapan tipe pembelajaran NHT dengan menggunakan mind mapping dapat meningkatkan hasil belajar peserta didik.

\section{PEMBAHASAN}

\section{Siklus I}

Pada pelaksanaan tindakan siklus I menunjukkan bahwa tahap-tahap penerapan penggunaan media mind mapping dengan tipe pembelajaran NHT pada

151 BRILLIANT: Jurnal Riset dan Konseptual

Volume 2 Nomor 2, Mei 2017 
materi luas bangun datar ini belum berjalan secara maksimal, masih terdapat kekurangan yang menuntut adanya perbaikan pada pembelajaran tindakan berikutnya. Kekurangan-kekurangan yang dimaksud diantaranya: (1) Guru masih belum bisa mengkondisikan kelas dengan baik, sehingga pada saat pembelajaran masih banyak peserta didik yang membuat gaduh, terutama pada saat peserta didik berdiskusi dengan kelompoknya masing-masing. (2) Dalam diskusi kelompok, peserta didik kurang maksimal dalam bekerja sama dengan anggota kelompoknya. Ada peserta didik yang masih belum memahami tugas yang telah didiskusikan, karena peserta didik dituntut memahami materi secara mandiri bersama kelompok tanpa penjelasan guru diawal pelajaran. (3) Peserta didik belum terbiasa dengan metode yang diberikan oleh guru sehingga pada saat guru menunjuk peserta didik secara acak untuk mempresentasikan hasil diskusinya di depan kelas dengan menggunakan media mind mapping, peserta didik masih belum percaya diri. (4) Hasil tes belajar yang diberikan pada akhir tindakan sebanyak 23 peserta didik yang belum tuntas dalam hasil belajarnya. Ketuntasan hasil belajar peserta didik secara klasikal melalui presentasi siklus I belum tercapai karena rata-rata ketuntasan hasil belajar klasikal kurang dari 70\%. (4) Hasil observasi aktivitas peserta didik menunjukan presentase keaktifan peserta didik kurang dari $80 \%$. Peserta didik belum mencapai presentase untuk dinyatakan dalam criteria peserta didik aktif dalam pembelajaran.

\section{Siklus II}

Pada pelaksanaan tindakan siklus II menunjukkan bahwa (1) Guru sudah bisa mengkondisikan kelas dengan baik, sehingga pada saat pembelajaran peserta didik sudah bisa tenang dan tertib. (2) Dalam diskusi kelompok, peserta didik sudah maksimal dalam bekerja sama dengan anggota kelompoknya. (3) Peserta didik sudah terbiasa dengan kondisi belajar yang menggunakan tipe pembelajaran NHT sehingga pada saat guru menunjuk peserta didik secara acak untuk mempresentasikan hasil diskusinya di depan kelas dengan menggunakan media mind mapping, peserta didik sudah lebih percaya diri. (4) Hasil tes belajar yang diberikan pada akhir tindakan, sebanyak 33 peserta didik sudah tuntas dalam hasil belajarnya dan hanya 7 peserta didik yang belum tuntas. Ketuntasan hasil belajar peserta didik secara klasikal melalui presentasi siklus II sudah tercapai karena rata-rata ketuntasan hasil belajar klasikal lebih dari 70\%. (5) Hasil observasi pada peserta didik mencapai presentase diatas $80 \%$ peserta didik aktif dalam pembelajaran. Sehingga pembelajaran telah dinyatakan tuntas.

\section{KESIMPULAN}

Berdasarkan hasil analisis data yang dilakukan peneliti pada Bab IV, dapat disimpulkan bahwa: (1) Penerapan media Mind Mapping dengan menggunakan pembelajaran Kooperatif tipe NHT dapat meningkatkan hasil belajar peserta didik kelas VI SDN Beloh pada materi luas bangun datar yang ditandai dengan peningkatan ketuntasan belajar peserta didik yaitu hasil ulangan sebelumnya sebesar $22,50 \%$, tes siklus I sebesar $42,50 \%$ dan tes siklus II sebesar $82,50 \%$ (2) Aktivitas peserta didik diperoleh dari observasi pada saat Penerapan media Mind Mapping dengan menggunakan pembelajaran Kooperatif tipe NHT dalam menyelesaikan masalah yang berkaitan dengan luas bangun datar. Pada siklus I presentase aktivitas peserta didik sebesar 60\% dan pada siklus II

152 BRILLIANT: Jurnal Riset dan Konseptual Volume 2 Nomor 2, Mei 2017 
mengalami peningkatan sebesar $30 \%$ menjadi $90 \%$. Sehingga dapat dikatakan bahwa ketuntasan aktivitas peserta didik telah tercapai pada siklus II.

\section{SARAN}

Berdasarkan hasil penelitian yang telah dilakukan, ada beberapa saran yang dapat diberikan oleh peneliti, yaitu sebagai berikut: (1) Sebelum proses belajar berlangsung, guru terlebih dahulu mempersiapkan rencana pelaksanaan pembelajaran supaya kelas bisa terkondisikan dengan baik. (2) Untuk menerapkan media Mind Mapping menggunakan pemeblejaran Kooperatif tipe NHT, peserta didik perlu banyak diberi motivasi dan penguatan agar peserta didik lebih giat dalam proses belajar mengajar dan berani mengemukakan pendapatnya di depan kelas. (3) Dalam rangka meningkatkan prestasi belajar siswa, guru hendaknya lebih sering melatih peserta didik dengan berbagai metode pembelajaran, walau dalam taraf yang sederhana, supaya peserta didik nantinya dapat menemukan pengetahuan baru, memperoleh konsep dan keterampilan, sehingga peserta didik berhasil atau mampu memecahkan masalah-masalah yang dihadapinya. (4) Untuk penelitian yang serupa hendaknya dilakukan perbaikan-perbaikan agar diperoleh hasil yang lebih baik.

\section{DAFTAR RUJUKAN}

Ahmadi, Rulam. 2014. Pengantar Pendidikan: Asas \& Filsafat Pendidikan. Yogyakarta: Ar-Ruzz Media.

Arikunto, Suharsimi,. 2002. Prosedur Penelitian. Jakarta: Rineka Cipta.

Ekawarna. 2011. Penelitian Tindakan Kelas. Jakarta: Gaung PersadaLindayani, D dan Murtadlo, M A. 2011. Manajemen Pembelajaran Inovatif. Surabaya: Iranti Mitra Utama.

Rozak, A dan Hidayati, W S. 2013. Pengolahan Data Dengan SPSS. Trowulan Mojokerto : STKIP PGRI Trowulan Mojokerto

Sardiman. 2011. Interaksi dan Motivasi Belajar Mengajar. Jakarta: PT Raja Grafindo Persada

Trianto. 2007. Model-model Pembelajaran Inovatif Beorientasi Kontruktivistik. Jakarta: Prestasi Pustaka. 